\title{
Drought sensitivity of beech on a shallow chalk soil in northeastern Germany - a comparative study
}

\author{
Marieke van der Maaten-Theunissen*, Hanna Bümmerstede, Janette Iwanowski, Tobias Scharnweber, \\ Martin Wilmking and Ernst van der Maaten
}

\begin{abstract}
Background: We compare the climate sensitivity of European beech (Fagus sylvatica L.) in two forest nature reserves in northeastern Germany. The one reserve, Schlossberg, is characterized by shallow chalk soils, whereas in the other reserve, Eldena, soils are deeper and more developed. Little is known about the drought sensitivity of beech on shallow chalk soils.

Methods: We collected increment cores at both research sites and established climate-growth relationships. Intertree variability was assessed by employing linear mixed-effect models.

Results: We expected to find distinctively higher drought sensitivity at Schlossberg due to limited water availability, but find only marginal differences in growth responses. At both sites, drought is the major climatic factor driving tree growth. Adaptations in tree architecture and an underestimation of the water holding capacity of shallow chalk soils are discussed as possible reasons for not finding more distinct climate responses. In analyzing climate-growth relationships, we specifically focused on growth responses of individual trees but observed only low inter-tree variability at both sites. Evident is a shift in climate response patterns from the first to the second half of the twentieth century with previous-year drought conditions becoming more important than current-year drought. This shift is discussed in relation to a warming trend over that same period, as well as possible trends in masting behavior of beech.
\end{abstract}

Conclusion: The investigated beech trees on the shallow chalk soil are only slightly more drought sensitive than beech trees on the reference site with deeper and more developed soils.

Keywords: Climate-growth relationships, Dendroecology, Inter-tree variability, Temporal stability, Drought stress

\section{Background}

European beech (Fagus sylvatica L.) is a tree species that naturally dominates over large parts of Central Europe due to a high competitiveness and physiological tolerance (Ellenberg 1996). The species thrives over broad environmental gradients and on many different bedrock types (Leuschner et al. 2006), but does not grow on extremely dry sites, on sites prone to flooding, on sites with high groundwater tables, or on stagnic soils (Ellenberg 1996). Next to being ecologically important, e.g., for biodiversity

\footnotetext{
* Correspondence: marieke.theunissen@uni-greifswald.de; marieketheunissen@gmail.com

Institute of Botany and Landscape Ecology, University of Greifswald, Soldmannstr. 15, 17487 Greifswald, Germany
}

(Moning and Müller 2009), beech is a major economic tree species in European silviculture (Geßler et al. 2007).

The climate sensitivity of beech has been investigated in many tree-ring based studies throughout the species distribution area (e.g. Chen et al. 2015; Friedrichs et al. 2009; García-Suárez et al. 2009; Lebourgeois et al. 2005; Scharnweber et al. 2011; van der Maaten 2012). These studies identified drought, in the previous and (or) current year, as a major growth-limiting factor. Despite its drought sensitivity, the resilience of beech to drought seems high. Van der Werf et al. (2007), for example, observed that growth of beech ceased during the extreme dry year 2003, but that it quickly recovered thereafter. In a future warmer climate, drought impacts are likely to become more severe, and may be particularly 
pronounced in the core of the species range as suggested by Cavin and Jump (2016). In their recent network study on beech, highest sensitivity and low resistance to drought is namely reported in the core of the species range, while dry range edge populations were characterized by particularly high drought resistance. Similarly, recent climate warming and increasing drought have impacted growth of beech more heavily on mesic sites compared to better adapted stands under marginal conditions (Weber et al. 2013). Although provenance may be a factor in explaining these differences as well, i.e. different provenances may exhibit different adaptive behavior (Bolte et al. 2007), the aforementioned studies show an important influence of local soil conditions on reaction and adaptation of beech to drought and emphasize the need for detailed evaluations of drought sensitivity in dependence of wideranging climatic and environmental conditions.

In investigating climate-growth relationships, tree-ring based studies mostly analyzed site chronologies that contain a maximized climate signal obtained by averaging tree-ring series of individual trees into one chronology (Fritts 1976). Variability in growth responses of individual trees, however, is ignored, and only general insights on how tree populations respond to climate fluctuations can be obtained. More recently, dendroecological studies started to explore the full range of tree-growth responses within sites by using individual-tree based approaches (e.g. Carrer 2011; Galván et al. 2014; Scharnweber et al. 2013;
Zang et al. 2014). In a climate change context, such studies are particularly important as the responses of individual trees will to a large degree determine how forest ecosystems may be affected by anticipated changes in climate.

In this study, we investigate the climate sensitivity of beech on a site with a shallow chalk soil in northeastern Germany. The water availability at such sites is assumed to be limited, and little is known on how these conditions translate into a drought signal in the growth record of beech. We compare the climate sensitivity of beech from a site with a shallow chalk soil with the sensitivity from a "typical" site in the same region, which has a deeper, more developed soil and a high water holding capacity. We hypothesize to find distinctively higher drought sensitivity for beech from the shallow chalk soil site. In analyzing climate-growth relationships, we not only consider mean stand chronologies, but also use tree-growth series from individual trees in linear mixed-effect models to explore the inter-tree variability in climate responses.

\section{Methods \\ Site description}

This study was conducted in two old-growth beech forests in northeastern Germany, named Schlossberg and Eldena (Fig. 1a). Both forests are nature reserves that were unmanaged for over 50 years. The nature reserve Schlossberg $\left(54.5307^{\circ} \mathrm{N}, 13.6515^{\circ} \mathrm{E}\right.$, elevation: $\left.135 \mathrm{~m}\right)$ is located on Rugia Island and lies within the borders of

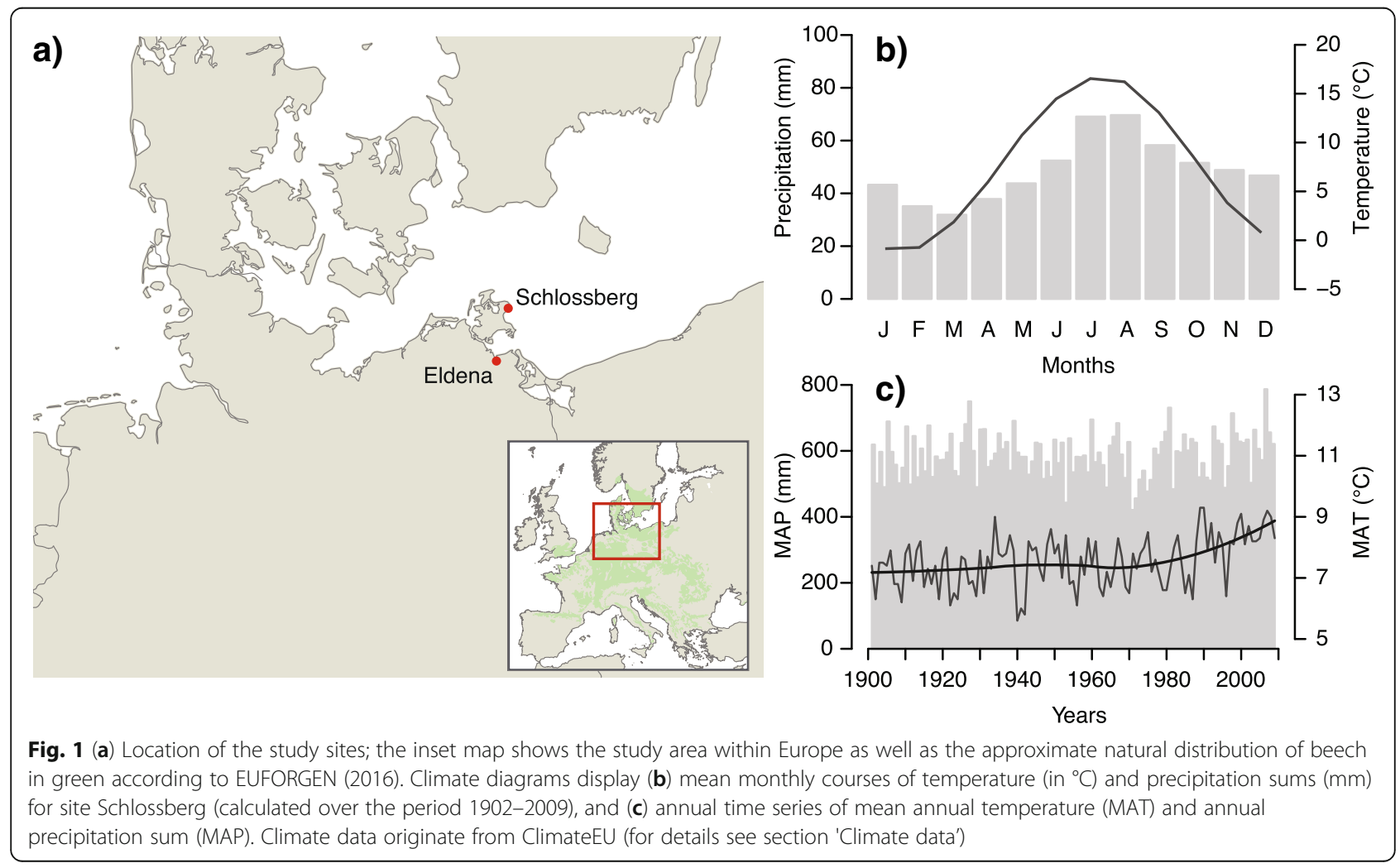


Jasmund National Park, of which part is declared UNESCO World Heritage Site ('Primeval Beech Forests of the Carpathians and the Ancient Beech Forests of Germany'). The forest nature reserve of Eldena $\left(54.0788^{\circ} \mathrm{N}, 13.4787^{\circ} \mathrm{E}\right.$, elevation: $\left.17 \mathrm{~m}\right)$ is located near the city of Greifswald, and, as Schlossberg, in close vicinity to the Baltic coast.

Both studied forests are situated in a Young Drift morainic landscape, but differ in their pedological characteristics. Typical for the Schlossberg site is a shallow chalk soil. Depending upon the soil depth, which can be highly variable at short distance (presence of chalky parent material ranging between a few centimeters and $>1 \mathrm{~m}$ ), soils can be characterized as leptosols (rendzinas), cambisols and luvisols (reference soil groups after the World Reference Base for Soil Resources; IUSS Working Group WRB 2015). According to the Dunham classification for carbonate sedimentary rocks (Dunham 1962), the chalk at Schlossberg can be characterized as a soft, weakly cemented biomicritic mudstone to wackestone, and only occasionally as floatstone with over $10 \%$ $>2 \mathrm{~mm}$ grains (Schnick 2002). At Eldena the parent material is sandy-loamy glacial till. Further, soils are deeper and more developed (i.e. no presence of leptosols, but only cambisols and luvisols), and locally there is influence of stagnating water and groundwater.

The regional climate can be characterized as temperate humid with a mean annual air temperature and precipitation sum of $7.5{ }^{\circ} \mathrm{C} / 576 \mathrm{~mm}$ and $8.1{ }^{\circ} \mathrm{C} / 562 \mathrm{~mm}$ at Schlossberg and Eldena, respectively. A climate diagram characterizing the general climate at Schlossberg (Fig. 1b) shows that precipitation sums are highest in summer. For Eldena, seasonal courses of temperature and precipitation are highly similar (see the difference plot of Additional file 1: Figure S1). In the second half of the twentieth century, increases in air temperature are evident, whereas no clear trends can be observed for precipitation (Fig. 1c).

\section{Tree-ring data}

We selected co-/dominant beech trees at Schlossberg $(n=25)$ and Eldena $(n=12)$, and extracted two increment cores at breast height from these trees. After air-drying, cores were either mounted on wooden holders and sanded with progressively finer grit sandpaper to highlight annual rings, or prepared for scanning in an ITRAX multiscanner (Cox Analytical Systems, Sweden). In both cases, tree-ring widths (TRW) were measured optically, and TRW-series for individual trees were obtained by averaging the measurements of the two cores. Visual and statistical crossdating of the tree-ring series was done using the CooRecorder/CDendro software package (Cybis Elektronik and Data $A B$, Sweden).
Ring-width series of individual trees were detrended by fitting a cubic smoothing spline with a $50 \%$ frequency cut-off at 30 years. This procedure accentuates climate-induced growth fluctuations while removing longer-term trends that may, for example, reflect tree ageing or disturbance (Cook and Peters 1981). Tree-ring indices were then calculated by dividing the observed by the predicted values. To characterize the developed index chronologies and to assess their quality, we report the common chronology statistics Gleichläufigkeit (glk), inter-series correlation (RBAR), mean sensitivity (MS), first-order autocorrelation (AC) and expressed population signal (EPS). Glk is the percentage of sign agreement in year-to-year ring-width changes, RBAR is the average correlation coefficient between all tree-ring series, MS is the average relative difference in tree growth between consecutive years, and $\mathrm{AC}$ is a measure of previous-year influence on current-year growth. EPS is a statistic used to assess the adequacy of the replication in a site chronology. We built chronologies and calculated chronology statistics using $d p l R$ (Bunn 2008).

\section{Climate data}

We obtained site-specific climate data using the software package ClimateEU (Hamann et al. 2013; Wang et al. 2012; available for download at http://tinyurl.com/Cli mateEU). This software front-end for interpolated climate databases, generated with the Parameter-elevation Regressions on Independent Slopes Model (PRISM) (Daly et al. 2008), allows to query 84 historical monthly, seasonal and annual climate variables for the years 19012009. An overview of all queried variables is provided as supplementary material (Additional file 1: Table S1).

\section{Statistical analyses}

We calculated bootstrapped correlation coefficients between site chronologies and climate data to identify climatic factors responsible for the observed growth variation. In these correlation analyses, we included monthly temperature (minimum, mean and maximum) and precipitation over a 16-month window from June of the previous year to September of the current year, as well as previous- and current-year seasonal and annual climate variables. Climate-growth relationships were established over the common period 1902-2009 using treeclim (Zang and Biondi 2015).

As the aforementioned climate-growth correlation analyses disregard inter-tree variability in climate responses (i.e. these standard analyses are based on average tree-growth indices of all sampled trees within a stand), we also employed linear mixed-effect models. By fitting these models on individual tree-growth indices with tree as random factor and climate variables as fixed effects, we could account for possible differences in 
climate response of single trees. The model can be formulated as follows:

$$
R W I_{i}=\alpha+\operatorname{Clim}_{i} \beta+b_{i}+\varepsilon_{i}
$$

where $R W I_{i}$ represents the growth index for tree $i, \alpha$ the intercept, $\mathrm{Clim}_{i}$ the fixed-effects matrix (i.e. climate variables), $\beta$ and $b_{i}$ vectors of fixed and random effects, and $\varepsilon_{i}$ a vector with random errors. We used the restricted maximum likelihood (REML) to determine the optimal random effects structure of our models (i.e. random intercept, random slope, or both random intercept and random slope), and maximum likelihood (ML) estimation to compare models with different fixed effects. We considered all climate variables from the climate-growth correlation analyses as fixed effects, but standardized them prior to model development (with a mean of 0 and a standard deviation of 1) to allow for direct comparison of model coefficients.

Linear mixed-effect models were built sequentially with up to three climate parameters. First, we tested all one-parameter models and compared their performance using the Akaike information criterion (AIC; Akaike 1974) corrected for small sample sizes $\left(\mathrm{AIC}_{\mathrm{c}}\right)$. AIC penalizes complex models with more parameters; smaller values indicate a more parsimonious model. We used the difference in $\mathrm{AIC}_{\mathrm{c}}$ between the null model and all candidate models $\left(\triangle \mathrm{AIC}_{\mathrm{c}}\right)$ to indicate the extent to which candidate models explain the variation in tree growth. In a second step, we added a second climate variable to the three best-performing one-parameter models. Similarly, a third climate variable was added to the three bestperforming two-parameter models. In adding a second and third climate variable, we excluded models with highly correlated explanatory variables (criterion: $r \geq 0.5$; cf. Ettinger et al. (2011) who used a 0.6-threshold). Next to model coefficients and $\Delta \mathrm{AIC}_{\mathrm{c}}$ values, we report the marginal $R^{2}$ (the variance explained by the fixed factors; calculated after Nakagawa and Schielzeth (2013) for all candidate models. In building and testing our linear mixed-effect models, we used the $\mathrm{R}$ packages nlme (Pinheiro et al. 2014) and piecewiseSEM (Lefcheck 2016).

To evaluate if climatic drivers of beech growth changed through time, we fitted linear mixed-effect models not only over the full climate data period (1902-2009), but also over an early and late sub-period (1902-1955 and 1956-2009, respectively).

\section{Results}

Metadata and chronology statistics for the study sites are provided in Table 1, site chronologies in Fig. 2. Remarkable is a higher tree age at Schlossberg (indicated by the mean segment length: 236 versus 200 years), but lower mean ring width. Chronology statistics for the
Table 1 Characteristics of the study trees

\begin{tabular}{llll}
\hline & Study site & & \\
\cline { 2 - 4 } & Characteristic & $\begin{array}{l}\text { Schlossberg } \\
\text { (shallow chalk soil) }\end{array}$ & $\begin{array}{l}\text { Eldena } \\
\text { (deeper soil) }\end{array}$ \\
\hline Raw data & No. of trees & 25 & 12 \\
& DBH $(\mathrm{cm})$ & $81.4(11.3)$ & $97.9(12.7)$ \\
& Height $(\mathrm{m})$ & $30.8(2.3)$ & $33.5(2.3)$ \\
& TRW $(\mathrm{mm})$ & $1.38(0.76)$ & $2.34(1.14)$ \\
Tree-ring indices & Segment length & $236(42)$ & $200(11)$ \\
& glk & 0.73 & 0.71 \\
& RBAR & 0.50 & 0.48 \\
& MS & 0.33 & 0.33 \\
& AC & 0.18 & 0.16 \\
& EPS & 0.96 & 0.92 \\
\hline
\end{tabular}

Average values are presented for $D B H$ diameter breast height, height tree height, TRW tree-ring width, segment length number of measured tree rings per tree. Values between parentheses denote standard deviations. glk Gleichläufigkeit, RBAR inter-series correlation, $M S$ mean sensitivity, $A C$ first-order autocorrelation, EPS expressed population signal. Mean TRW and statistics of tree-ring indices are presented for the period 1902-2009

developed index chronologies, however, are highly similar. High values for glk and RBAR indicate that trees show similar growth patterns within the individual sites. Also between sites similarities in growth patterns are evident; index chronologies are strongly correlated $(r=0.72$; period 1902-2009). MS values of 0.33 point to high year-to-year variability in growth. Finally, EPS-values beyond the commonly used threshold of 0.85 indicate a coherent standlevel signal.

The climate-growth correlation analyses indicate that previous-year summer temperature is a significant negative determinant of beech growth at both sites (Fig. 3). At the same time, previous-year summer precipitation positively affects beech growth, pointing to possible drought stress. Correlations with annual climate variables substantiate the importance of previous-year drought for current-year's growth (Additional file 1: Figure S2). Also for the current year, a drought signal is suggested by positive correlations with spring and June precipitation as well as negative correlations with mean June temperature. Although there are some differences in correlation strengths for individual climate parameters, general correlation patterns are remarkably similar for Schlossberg and Eldena.

At the individual tree level, random intercept linear mixed-effect models revealed previous-year drought conditions as an important growth-limiting factor as well. At the Schlossberg site, this is illustrated by negative effects of previous-year July maximum temperature (pTmax07) and positive effects of previous-year August precipitation (pPPT08) in numerous best-fit models (Table 2). For Eldena, the previous-year climate moisture 

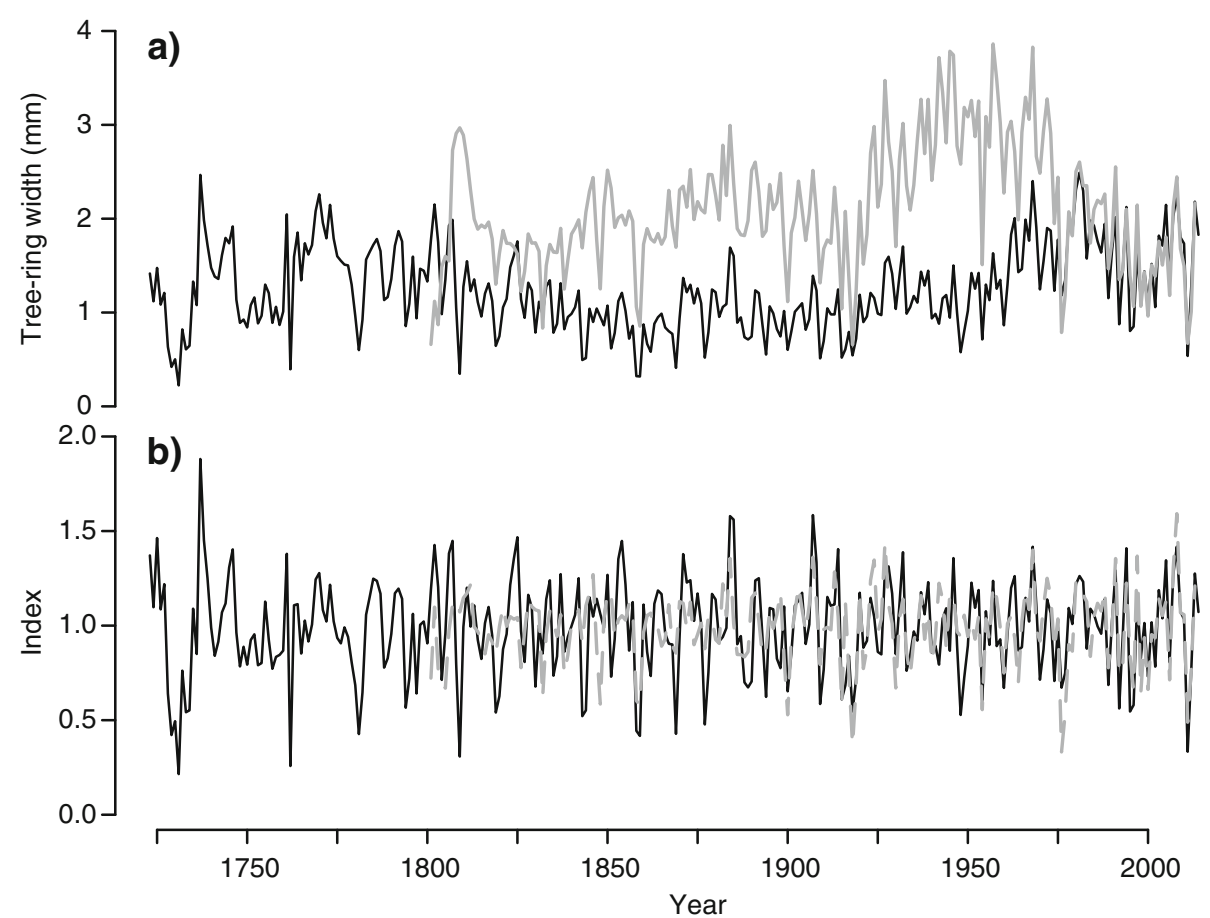

Fig. 2 (a) Raw tree-ring width and (b) detrended index chronologies for Schlossberg (black) and Eldena (gray)
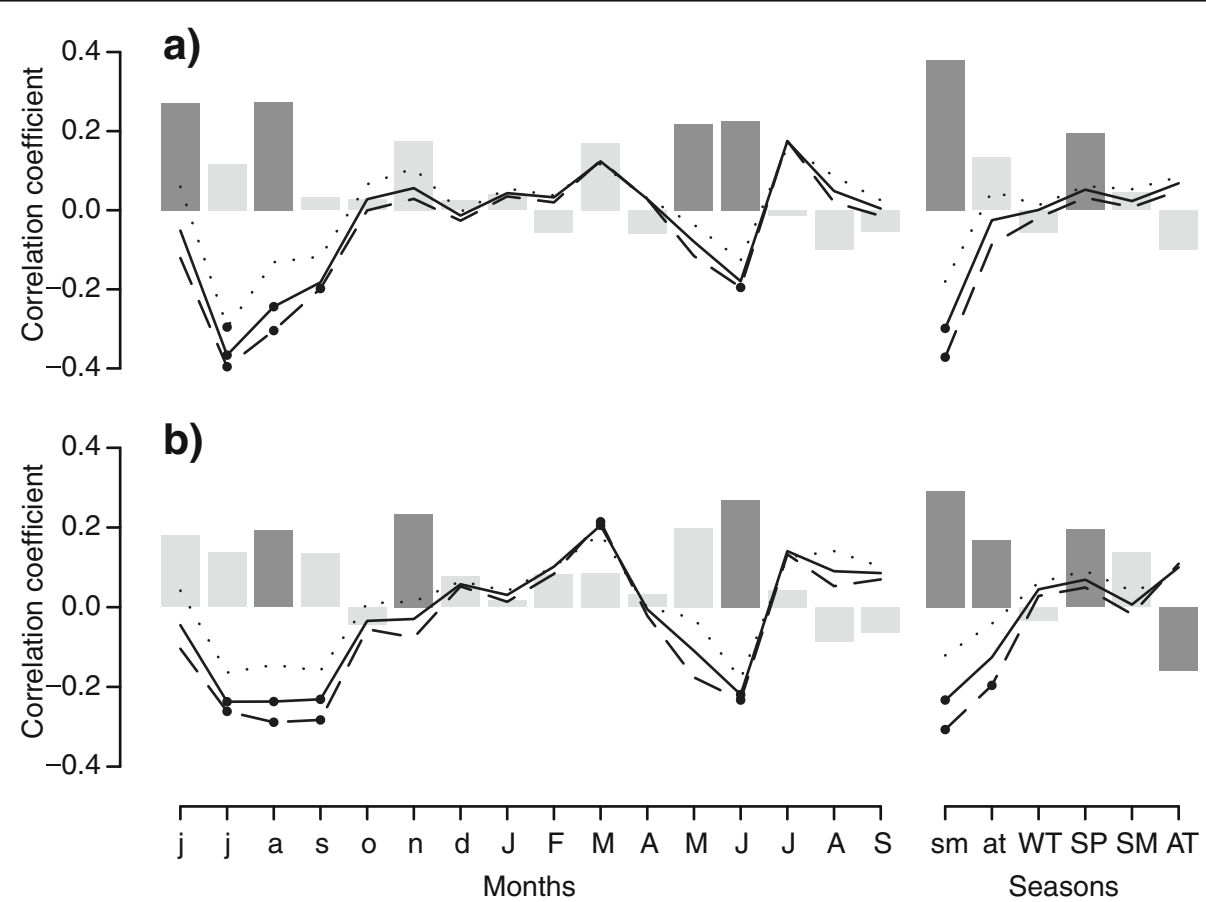

Fig. 3 Results of the bootstrapped correlation analysis between tree-growth indices and monthly and seasonal climate data for (a) Schlossberg and (b) Eldena. Bars indicate correlations for precipitation, lines for temperature (dotted line: mimimum temperature; solid line: average temperature; dashed line: maximum temperature). Significant correlations $(P<0.05)$ are indicated by dark gray bars (for precipitation) and filled circles (for temperature). Months and seasons are abbreviated with lower- and uppercase letters for the previous- and current-year growing season, respectively. WT winter (December (previous year) - February), SP spring (March - May), SM summer (June - August), AT autumn (September - November) 
Table 2 Statistical parameters of the three best-performing linear mixed-effect models of tree-ring indices with one, two or three climate variables for site Schlossberg

\begin{tabular}{|c|c|c|c|c|c|c|c|c|}
\hline & \multicolumn{6}{|l|}{ Coefficients } & \multirow[t]{2}{*}{$\Delta \mathrm{AlC}_{\mathrm{c}}$} & \multirow[t]{2}{*}{$R^{2}(\%)$} \\
\hline & $\mathrm{p} 1$ & $\mathrm{cl}$ & $\mathrm{p} 2$ & $c 2$ & p3 & c3 & & \\
\hline \multirow[t]{10}{*}{ Full period (1902-2009) } & null model & & & & & & - & 0.0 \\
\hline & pPPT_sm & 0.09 & & & & & 204.6 & 7.4 \\
\hline & pSHM & -0.09 & & & & & 207.1 & 7.5 \\
\hline & pTmax07 & -0.09 & & & & & 223.8 & 8.0 \\
\hline & pTmax07 & -0.07 & pPPT_sm & 0.07 & & & 341.6 & 12.0 \\
\hline & pTmax07 & -0.08 & pMAP & 0.07 & & & 374.8 & 13.1 \\
\hline & pTmax07 & -0.10 & рРРТ08 & 0.07 & & & 377.1 & 13.2 \\
\hline & pTmax07 & -0.09 & pMAP & 0.06 & pbFFP & -0.05 & 451.4 & 15.6 \\
\hline & pTmax07 & -0.11 & рРPT08 & 0.07 & pNFFD & 0.05 & 457.6 & 15.8 \\
\hline & pTmax07 & -0.11 & рРРТ08 & 0.06 & pbFFP & -0.05 & 459.7 & 15.8 \\
\hline \multirow[t]{10}{*}{ Early period (1902-1955) } & null model & & & & & & - & 0.0 \\
\hline & PPT_sp & 0.09 & & & & & 110.9 & 8.0 \\
\hline & pPPT_sm & 0.09 & & & & & 115.1 & 8.3 \\
\hline & РPT05 & 0.10 & & & & & 119.1 & 8.6 \\
\hline & PPT_sp & 0.10 & рРPT06 & 0.10 & & & 247.2 & 17.0 \\
\hline & PPT05 & 0.10 & рPРT06 & 0.10 & & & 251.6 & 17.3 \\
\hline & pPPT_sm & 0.10 & PPT_sp & 0.10 & & & 267.1 & 18.2 \\
\hline & PPT_sp & 0.11 & рPРT06 & 0.08 & рPРT08 & 0.07 & 323.2 & 21.7 \\
\hline & PPT_sp & 0.11 & рPРT06 & 0.10 & Tmax06 & -0.07 & 323.8 & 21.7 \\
\hline & pPPT_sm & 0.12 & PPT_sp & 0.09 & pTmin11 & 0.07 & 330.3 & 22.1 \\
\hline \multirow[t]{10}{*}{ Late period (1956-2009) } & null model & & & & & & - & 0.0 \\
\hline & pSHM & -0.10 & & & & & 132.4 & 9.5 \\
\hline & pTave07 & -0.10 & & & & & 148.1 & 10.5 \\
\hline & pTmax07 & -0.10 & & & & & 152.8 & 10.8 \\
\hline & pTmax07 & -0.11 & рРРТ08 & 0.07 & & & 228.1 & 15.8 \\
\hline & pTave07 & -0.10 & PРT06 & 0.08 & & & 242.1 & 16.7 \\
\hline & pTmax07 & -0.11 & PРT06 & 0.08 & & & 245.1 & 16.9 \\
\hline & pTave07 & -0.09 & PPT06 & 0.08 & PPPT_sm & 0.06 & 288.8 & 19.6 \\
\hline & pTave07 & -0.11 & РPT06 & 0.07 & рPРT08 & 0.06 & 300.1 & 20.3 \\
\hline & pTmax07 & -0.11 & РРТ06 & 0.07 & рРPT08 & 0.06 & 305.4 & 20.6 \\
\hline
\end{tabular}

Best-fit models are presented based on the full climate data period (1902-2009), an early period (1902-1955), and a late period (1956-2009). The presented null models consider constant tree-ring indices

p1-p3 climate predictors 1 to 3, c1-c3 coefficients of fixed effects, $\triangle A I C_{c}$ corrected AIC value (AIC $c$ ) of the null model minus the AICc of the tested model, $R^{2}$ marginal explained variance. Climate predictors are abbreviated as in Additional file 1: Table S1. The most frequent climate predictor for each period is indicated in bold

deficit (pCMD) was found as a major growth determinant (Table 3). For the one-parameter models, climate response patterns are consistent with the results of the correlation analysis (Additional file 1: Figures S3-S6).

In the two sub-periods 1902-1955 and 1956-2009, drought signals are evident as well, but are expressed through different climate predictors. In the early period, current-year climate parameters prevail (Schlossberg: PPT_sp; Eldena: Tmax06 and PPT_sp), whereas carryover effects of drought seem less important (i.e. expressed by relatively few previous-year drought parameters). In the late period, on the other hand, previous-year climate parameters prevail with previous July and summer (maximum) temperature as the most frequent climate determinants (pTmax07/pTave07 and pTmax_sm) at Schlossberg and Eldena, respectively.

The explained variance of all best-fit one- to threeparameter models ranged between 4.9 and $22.1 \%$, with marginal $\mathrm{R}^{2}$-values being consistently higher for the early and late sub-period compared to the full period. 
Table 3 Statistical parameters of the best-performing linear mixed-effect models for site Eldena. See further the table legend and footnotes of Table 2

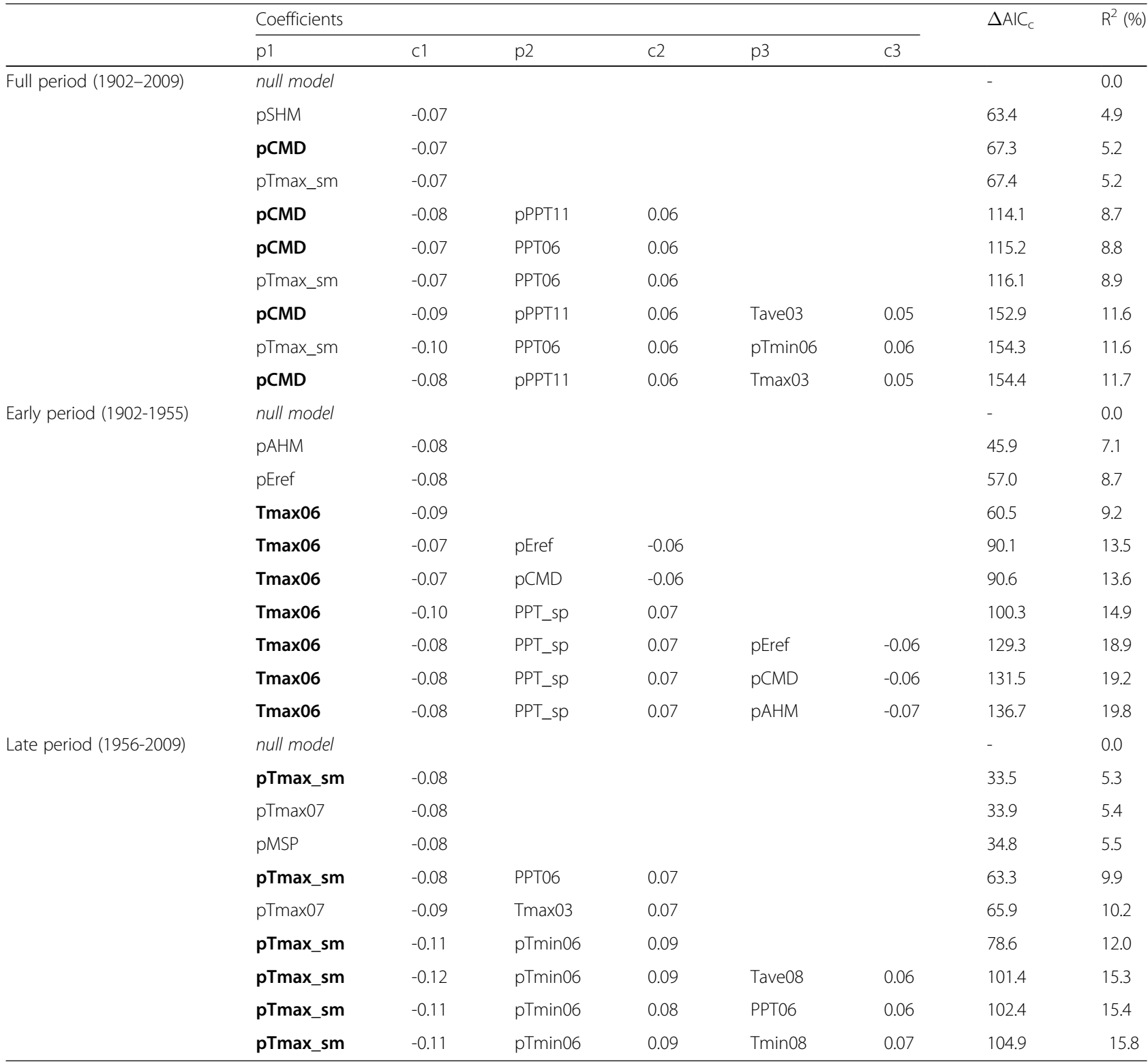

Further, the explained variance for Schlossberg is higher than for Eldena, which implies that drought parameters better explain the observed growth variation, suggesting a (slightly) higher drought sensitivity of beech at Schlossberg. Overall, the inter-tree variability in climatic responses was low with variance components for the random tree effect approaching zero.

\section{Discussion}

Individual trees showed strong common growth signals at our research sites as evidenced by high values for glk, RBAR and EPS (Table 1), as well as by a low inter- tree variability observed in our climate-driven linear mixed-effect models of tree-growth indices. These results underline that the investigated trees are affected by a common climatic factor, i.e. drought, and that our sampling of co-/dominant trees resulted in a uniform dataset without much inter-tree variability. On the contrary, studies that not only sampled dominant trees but also intermediate and (or) suppressed trees (e.g. Cescatti and Piutti 1998; Martín-Benito et al. 2008) report intertree variability. Larger beech trees (like we sampled in our study) were found to be more sensitive to summer drought than smaller trees (e.g. Mérian and Lebourgeois 
2011), which likely relates to higher evaporative water losses that large trees face because of their large crowns (Střelcová et al. 2002).

Both in the classical climate-growth correlation analyses (Fig. 3 and Additional file 1: Figure S2) as well as in our linear mixed-effect models (Tables 2 and 3, Additional file 1: Figures S3-S6) drought signals prevailed at Schlossberg and Eldena. Although climate response patterns were highly similar, a higher explained variance of the models for Schlossberg suggests that this site is slightly more drought sensitive. As a possible explanation for the lower-than-expected drought sensitivity of beech at Schlossberg, we hypothesize that adaptations in tree architecture safeguarded the beech trees from severe drought problems at the site (Kahle 1994; van der Maaten et al. 2013). This hypothesis is supported by our metadata showing that, although trees at Schlossberg are older than at Eldena, tree height and DBH are lower (Table 1), which likely results in a lower demand for water. As an alternative explanation, we propose that the water holding capacity of the shallow chalk soils might be higher than assumed. Although the available water capacity of the upper soil is lower at Schlossberg (i.e. soils are shallow), the local chalk bedrock shows a fine texture with relatively high silt and clay contents and is full of fissures. This probably contributes to relatively good water storage capacities of the bedrock, which is plant available if the trees are able to penetrate the parent material with their roots. That shallow chalk soils can supply enough water for plant growth is also suggested by a study on the productivity of agricultural crops in England, which reports that even the shallowest chalk soils $(23 \mathrm{~cm})$ provide enough water to sustain good yields (Burnham and Mutter 1993).

We found drought signals in our models for Schlossberg and Eldena for both the full climate data period (1902-2009), as well as for the early and late sub-periods (1902-1955 and 1956-2009, respectively). Although climate response patterns remained relatively stable over time, a shift in importance from current to previous-year drought influences was observed from the early to the late sub-period. Next to possible effects of ageing, this shift might relate to a co-occurring temperature increase in the second half of the twentieth century (Fig. 1c). Namely, higher temperatures may increase evaporative water losses, thereby making last years' water status more important. Next to direct effects of the previous-year water budget on the current-year growth, previous-year drought effects may also be explained over floral induction (Di Filippo et al. 2007). Various studies showed that hot and dry summer conditions stimulate masting in beech in the following year (Piovesan and Adams 2001; Schmidt 2006), thereby negatively affecting growth (Dittmar et al. 2003; Drobyshev et al. 2010). In line with these results, Hacket-
Pain et al. (2015) showed that regression models explained growth of beech equally well when replacing previousyear maximum temperature by current-year seed production. Although there is no data available on beech masting at Schlossberg and Eldena, a general observation of more frequent and intense fructification in Germany over recent decades (Paar et al. 2011) suggests that masting may also be a likely cause for the shift from current- to previousyear drought parameters in our models.

In contrast to classical dendroecological studies that aim for strong climatic signals by averaging individual tree-growth series into a site chronology (Fritts 1976), we employed an additional linear mixed-effect modeling exercise. Rather than filtering-out tree-specific signals by averaging over multiple trees, which is a process that might be beneficial for climate reconstructions, linear mixed-effect models use the growth series of all trees while estimating a model true for the whole population. The models provide insight into the variability in growth responses of individual trees to climate, thereby providing essential information on the range of tree species responses to climate, and consequently on how they may respond to future climate changes. Even though inter-tree variability was low in our tree-ring dataset (i.e. variance components for the random tree effect were approaching zero), we support Carrer (2011) in advocating an increased focus on climate responses of individual trees in the future. From recent individual tree-based studies, we learned, amongst others, that growth sensitivity may increase with age (Linares et al. 2013), or that the variability in individual-tree responses during and after drought events may be high (Zang et al. 2014). Such insights are of upmost importance in the face of climate change, as it will not be the averaged responses of forest stands, but the growth responses of individual trees that will determine how forests may be affected in the future.

\section{Conclusion}

We compared the climate sensitivity of European beech on a shallow chalk soil in northeastern Germany with beech trees on a site with deeper and more developed soils, and found that beech is only slightly more drought sensitive on the shallow chalk soil.

\section{Additional file}

Additional file 1: Supplementary figures and table. (PDF 193 kb)

\section{Acknowledgments}

We thank the Jasmund National Park and the forest service of the University of Greifswald for supporting our fieldwork.

Funding

MMT and EM acknowledge support by a research grant of the Eva Mayr-Stihl Foundation. MMT and MW are participating researchers of the research training group RESPONSE, funded by the German Research Council (DFG GRK2010). 


\section{Authors' contributions}

Conceived and designed the study: MMT and EM. Performed the field- and lab-work: MMT, HB, JI, TS, EM. Analyzed the data: MMT and EM. Wrote the manuscript: MMT, TS, MW, EM. All authors read and approved the final manuscript.

\section{Author's information}

MMT, EM and TS are postdoctoral forest ecologists mainly working in European forests. They have a special interest in understanding the role of plasticity and adaptation of tree species in assessing potential impacts of climate change. Professor MW is a geo-ecologist working on the ecosystem dynamics of trees and shrubs in temperate and boreal regions, as well as the arctic tundra. $\mathrm{HB}$ and $\mathrm{JI}$ are graduate students that wrote their Bachelor theses on the ecology of beech in Jasmund national park. All authors are working at (or associated to) the Institute of Botany and Landscape Ecology at the University of Greifswald, Germany.

\section{Competing interests}

The authors declare that they have no competing interests.

\section{Field permits}

Research permissions to sample European beech trees at Schlossberg and Eldena were provided by the Jasmund National Park and the lower nature conservation authority Vorpommern-Greifswald, respectively.

Received: 21 July 2016 Accepted: 7 September 2016

\section{Published online: 16 September 2016}

\section{References}

Akaike H (1974) A new look at the statistical model identification. IEEE Trans Autom Control 19:716-723

Bolte A, Czajkowski T, Kompa T (2007) The north-eastern distribution range of European beech - A review. Forestry 80:413-429

Bunn AG (2008) A dendrochronology program library in R (dpIR). Dendrochronologia 26:115-124

Burnham CP, Mutter GM (1993) The depth and productivity of chalky soils. Soil Use Manage 9:1-8

Carrer M (2011) Individualistic and time-varying tree-ring growth to climate sensitivity. PLoS ONE 6:e22813

Cavin L, Jump AS (2016) Highest drought sensitivity and lowest resistance to growth suppression are found in the range core of the tree Fagus sylvatica $\mathrm{L}$. not the equatorial range edge. Global Change Biol doi:10.1111/gcb.13366

Cescatti A, Piutti E (1998) Silvicultural alternatives, competition regime and sensitivity to climate in a European beech forest. Forest Ecol Manage 102 : 213-223

Chen K, Dorado-Linan I, Akhmetzyanov L, Gea-Izquierdo G, Zlatanov T, Menzell A (2015) Influence of climate drivers and the North Atlantic Oscillation on beech growth at marginal sites across the Mediterranean. Clim Res 66:229-242

Cook ER, Peters K (1981) The smoothing spline: a new approach to standardizing forest interior tree-ring width series for dendroclimatic studies. Tree-Ring Bull 41:45-53

Daly C, Halbleib M, Smith Jl, Gibson WP, Doggett MK, Taylor GH, Curtis J, Pasteris PP (2008) Physiographically sensitive mapping of climatological temperature and precipitation across the conterminous United States. Int J Clim 28:2031-2064

Di Filippo A, Biondi F, Čufar K, De Luis M, Grabner M, Maugeri M, Presutti Saba E, Schirone B, Piovesan G (2007) Bioclimatology of beech (Fagus sylvatica L.) in the Eastern Alps: spatial and altitudinal climatic signals identified through a tree-ring network. J Biogeogr 34:1873-1892

Dittmar C, Zech W, Elling W (2003) Growth variations of common beech (Fagus sylvatica L.) under different climatic and environmental conditions in Europe - A dendroecological study. Forest Ecol Manage 173:63-78

Drobyshev I, Övergaard R, Saygin I, Niklasson M, Hickler T, Karlsson M, Sykes MT (2010) Masting behavior and dendrochronology of European beech (Fagus sylvatica L.) in southern Sweden. Forest Ecol Manage 259:2160-2171

Dunham RJ (1962) Classification of carbonate rocks according to depositional texture. In: Ham WE (ed) Classification of Carbonate Rocks, American Association of Petroleum Geologists Memoir 1, pp 108-121

Ellenberg H (1996) Vegetation Mitteleuropas mit den Alpen in ökologischer dynamischer und historischer Sicht. Ulmer, Stuttgart, Germany

Ettinger AK, Ford KR, HilleRisLambers J (2011) Climate determines upper, but not lower, altitudinal range limits of Pacific Northwest conifers. Ecology 92:1323-1331
EUFORGEN (2016) Distribution maps - Fagus sylvatica L. www.euforgen.org. Accessed 20 June 2016.

Friedrichs DA, Trouet V, Büntgen U, Frank DC, Esper J, Neuwirth B, Löffler J (2009) Species-specific climate sensitivity of tree growth in Central-West Germany. Trees 23:729-739

Fritts HC (1976) Tree rings and climate. Academic, London

Galván JD, Camarero JJ, Gutiérrez E, Zuidema P (2014) Seeing the trees for the forest: drivers of individual growth responses to climate in Pinus uncinata mountain forests. J Ecol 102:1244-1257

García-Suárez AM, Butler CJ, Baillie MGL (2009) Climate signal in tree-ring chronologies in a temperate climate: a multi-species approach. Dendrochronologia 27:183-198

Geßler A, Keitel C, Kreuzwieser J, Matyssek R, Seiler W, Rennenberg H (2007) Potential risks for European beech (Fagus sylvatica L.) in a changing climate. Trees 21:1-11

Hacket-Pain AJ, Friend AD, Lageard JGA, Thomas PA (2015) The influence of masting phenomenon on growth-climate relationships in trees: explaining the influence of previous summers' climate on ring width. Tree Physiol 35: 319-330

Hamann A, Wang T, Spittlehouse DL, Murdock TQ (2013) A comprehensive, highresolution database of historical and projected climate surfaces for Western North America. Bull Am Meteorol Soc 94:1307-1309

IUSS Working Group WRB (2015) World Reference Base for Soil Resources 2014, update 2015 International soil classification system for naming soils and creating legends for soil maps. World Soil Resources Reports, vol 106. FAO, Rome.

Kahle H (1994) Modellierung der Zusammenhänge zwischen der Variation von klimatischen Elementen des Wasserhaushalts und dem Radialzuwachs von Fichten (Picea abies (L.) Karst.) aus Hochlagen des Südschwarzwalds: eine standortbezogene dendroökologische Untersuchung unter besonderer Berücksichtigung von Trockenstreß. Institute for Forest Growth, AlbertLudwigs-University, Freiburg, p 184

Lebourgeois F, Bréda N, Ulrich E, Granier A (2005) Climate-tree-growth relationships of European beech (Fagus sylvatica L.) in the French Permanent Plot Network (RENECOFOR). Trees 19:385-401

Lefcheck JS (2016) piecewiseSEM: Piecewise structural equation modelling in $\mathrm{R}$ for ecology, evolution, and systematics. Methods Ecol Evol 7:573-579

Leuschner C, Meier IC, Hertel D (2006) On the niche breadth of Fagus sylvatica: soil nutrient status in 50 Central European beech stands on a broad range of bedrock types. Ann For Sci 63:355-368

Linares JC, Taïqui L, Sangüesa-Barreda G, Seco Jl, Camarero JJ (2013) Age-related drought sensitivity of Atlas cedar (Cedrus atlantica) in the Moroccan Middle Atlas forests. Dendrochronologia 31:88-96

Martín-Benito D, Cherubini P, del Río M, Cañellas I (2008) Growth response to climate and drought in Pinus nigra Arn. trees of different crown classes. Trees 22:363-373

Mérian P, Lebourgeois F (2011) Size-mediated climate-growth relationships in temperate forests: a multi-species analysis. Forest Ecol Manage 261:1382-1391

Moning C, Müller J (2009) Critical forest age thresholds for the diversity of lichens, molluscs and birds in beech (Fagus sylvatica L.) dominated forests. Ecol Indic 9:922-932

Nakagawa S, Schielzeth H (2013) A general and simple method for obtaining $\mathrm{R}^{2}$ from generalized linear mixed-effects models. Methods Ecol Evol 4:133-142

Paar U, Guckland A, Dammann I, Albrecht M, Eichhorn J (2011) Häufigkeit und Intensität der Fruktifikation der Buche. AFZ-Der Wald 6:26-29

Pinheiro J, Bates D, DebRoy S, Sarkar D (2014) nlme: linear and nonlinear mixed effects models. R package version 3.1-125.

Piovesan G, Adams JM (2001) Masting behaviour in beech: linking reproduction and climatic variation. Can J Bot 79:1039-1047

Scharnweber T, Manthey M, Criegee C, Bauwe A, Schröder C, Wilmking M (2011) Drought matters - Declining precipitation influences growth of Fagus sylvatica L. and Quercus robur L. in north-eastern Germany. Forest Ecol Manage 262:947-961

Scharnweber T, Manthey M, Wilmking M (2013) Differential radial growth patterns between beech (Fagus sylvatica L.) and oak (Quercus robur L.) on periodically waterlogged soils. Tree Physiol 33:425-437

Schmidt W (2006) Temporal variation in beech masting (Fagus sylvatica L.) in a limestone beech forest (1981-2004). Allg Forst Jagdztg 177:9-19

Schnick HH (2002) The Jasmund cliff section. Greifswalder Geographische Arbeiten 27:69-73

Střelcová K, Matejka F, Mindáš J (2002) Estimation of beech tree transpiration in relation to their social status in forest stand. J For Sci (Prague) 48:130-140 
van der Maaten E (2012) Climate sensitivity of radial growth in European beech (Fagus sylvatica L.) at different aspects in southwestern Germany. Trees 26: 777-788

van der Maaten E, Bouriaud O, van der Maaten-Theunissen M, Mayer H, Spiecker H (2013) Meteorological forcing of day-to-day stem radius variations of beech is highly synchronic on opposing aspects of a valley. Agric For Meteorol 181:85-93

van der Werf GW, Sass-Klaassen UGW, Mohren GMJ (2007) The impact of the 2003 summer drought on the intra-annual growth pattern of beech (Fagus sylvatica L.) and oak (Quercus robur L.) on a dry site in the Netherlands. Dendrochronologia 25:103-112

Wang T, Hamann A, Spittlehouse DL, Murdock TQ (2012) ClimateWNA - Highresolution spatial climate data for Western North America. J Appl Meteorol Climatol 51:16-29

Weber P, Bugmann H, Pluess AR, Walthert L, Rigling A (2013) Drought response and changing mean sensitivity of European beech close to the dry distribution limit. Trees 27:171-181

Zang C, Biondi F (2015) treeclim: an R package for the numerical calibration of proxy-climate relationships. Ecography 38:431-436

Zang C, Hartl-Meier C, Dittmar C, Rothe A, Menzel A (2014) Patterns of drought tolerance in major European temperate forest trees: climatic drivers and levels of variability. Global Chang Biol 20:3767-3779

\section{Submit your manuscript to a SpringerOpen ${ }^{\circ}$ journal and benefit from:}

- Convenient online submission

- Rigorous peer review

- Immediate publication on acceptance

- Open access: articles freely available online

- High visibility within the field

- Retaining the copyright to your article

Submit your next manuscript at $\boldsymbol{s p r i n g e r o p e n . c o m ~}$ 